\title{
Disability management: The Insurance Corporation of British Columbia experience
}

\author{
Henry Harder*/ Leslie Potts**
}

\section{Introduction}

The Insurance Corporation of British Columbia (ICBC) is a Crown Corporation created by the Provincial Government in 1974 to provide compulsory auto insurance. It is a commonlaw or tort system with "add-on" no-fault provisions (medical/rehabilitation and disability benefits). ICBC insures 2 million British Columbia (BC) residents and pays out over $\$ 2$ billion (Cdn.) in claims annually. One billion of this is for injury claims. Currently, one percent of these claims are catastrophic losses (paraplegic, quadriplegic, traumatic brain injury) with the remainder being non-catastrophic claims. Seventy percent of these non-catastrophic claims are soft tissue (primarily whiplash) injuries.

ICBC has been actively involved in the identification and application of "best practice" soft-tissue injury initiatives and case coordination strategies since 1994. Previously, interest in rehabilitation programs was concentrated on the support of those customers who sustained catastrophic injuries. ICBC's Rehabilitation Department has been assisting these seriously injured customers since 1974 and is respected within both the medical and legal communities.

A key challenge for ICBC was to better assist customers with non-catastrophic injuries. In British Columbia disability periods are longer than in other jurisdictions (internal ICBC data). The functional limitations experienced by ICBC's injured customers appear to be out of keeping with the severity of their injuries. This is particularly true for those customers that sustain soft tissue injuries. These functional limitations and the subsequent time away from work translate into more monies paid out for lost wages. Many of these customers' pain complaints become chronic. In 2000, ICBC paid out $\$ 108,532,000$ for past wage loss claims and $\$ 127,108,000$ for future wage loss claims. Disability is also a factor in assessing non-pecuniary damages (pain and suffering) resulting in greater amounts being paid out under this category of damage as well. The frustration experienced by these injured customers may also cause them to seek legal representation, which in turn complicates and increases the costs of resolving these claims.

The solution appeared to lie in finding an approach where ICBC could assist with the recovery process and manage costs without assuming responsibility for "managing" the customers injuries. In an attempt to provide services based on this philosophy, ICBC launched the Recovery Management Program (RMP) in 1995. In this model qualified external resources, primarily occupational therapists, were contracted by Bodily Injury (BI) Adjusters to establish individual rehabilitation plans administered and provided within the community. The customers and their attending physician were at the centre of this case coordination model.

Although this program was partially successful in that it opened the lines of communication with the medical community, its success was restricted largely due to limited acceptance and sporadic utilization. Contributing factors were insufficient external resources and lack of dedicated internal resources to ensure proper referral and monitoring of rehabilitation plans. Although the program's focus did reverse high-growth trends in wage loss payments, it was unclear whether this was related to individual plans or to a general increase in awareness and focus in managing disabilities both externally and internally. In fact an independent evaluation, commissioned by ICBC to determine the overall effectiveness of the Recovery Management Program, was unable to conclude if there had been a decrease in costs. The reason for this was that the researchers could not find a comparable match sample. The customers referred into the Recovery Management Program had a higher incidence of employment, higher earnings and were more seriously injured (headaches, neurological signs). Despite these factors the RMP group did report that they were more satisfied with their level of recovery (RMP 43\% vs. Match group 22\%) and more reported that they had completely recovered (RMP $72 \%$ vs. Match group 50\%) (RMP evaluation 1998 - Internal ICBC document.)

Qualitative data showed that while the majority of doctors surveyed sanctioned the legitimacy of ICBC's role, internal support varied. The data also showed differences in the perceptions of the program' goals between the customer's doctor, the external case managers and the adjusters. While the doctors were interested in sustaining relationships with their clients and the case coordinators were interested in the delivery of service, the adjuster's goals were economic and were cost driven. Eventually, even those BI adjusters who were supportive began opting out due to lack of ongoing support and useful evaluative data.

Nevertheless, based on a conviction that the initial concept was valid, and armed with knowledge that only experience can bring, ICBC decided to take the lessons learned in RMP and create a new program called Injury Recovery.

Injury recovery program (IRP)

The inability to return to work post MVA can be termed

\footnotetext{
*Chair, Disability Management Program, The University of Northern British Columbia; **Manager, Bodily Injury Operations Support,

The Insurance Company of British Columbia, Canada

Correspondence and reprints: Dr Henry G Harder, Disability Management Program, University of Northern British Columbia,

3333 University Way, Prince George, BC, V2N 4Z9, Telephone 250-960-6506, fax 250-960-5744, e-mail harderh@unbc.ca
} 
"traumatically induced unemployment". If an impairment, which results from a disability caused by a motor vehicle accident (MVA) leads to unemployment, the consequences to the individual are the same as those of any other type of unemployment. Consequently, IRP drew heavily from the unemployment research for its support.

Researchers have examined the impact of unemployment on particular groups (BALDWIN \& JOHNSON, 1998; BRENNER \& LeVI, 1987; BRICOUT \& BentLey, 2000; JAHOdA, 1982; Tiggemann \& Winefield, 1984; Winefield, Tiggeman \& WINEFIELD, 1991). The literature also contains many studies that demonstrate the importance of work in establishing a healthy identity (Kelvin, 1981; Orwell, 1972; SChaufeli, 1988) and the resulting psychological impact of unemployment (Dooley \& Catalano, 1988; Dyck, 2000; Gurney, 1980; Kaufman, 1982; Rump, 1983; Shaw, 1976; Shelton, 1985; Winefield, Tiggeman \& SMith, 1987; Winefield, Tiggeman, \& Winefield, 1991). The impact of unemployment on the disabled is similar (BORGEN, AMUNDSON \& Biela, 1987; Thomason, Burton \& HyatT, 1998). Acton (1981) identified four reasons why work is an essential goal for disabled persons: (a) they need the income derived from gainful employment, (b) nearly all cultures place a high value on work as a part of a rich and complete life, (c) it is a way to form social relationships, and (d) it gives structure and discipline to living. MASLOW (1968) AND TOFFLER (1980) consider these to be basic needs for everyone.

While the needs of persons with disabilities are similar to the general population, they do face special challenges in becoming employed (BEAN \& BEARD, 1975; COHEN, 1962; Eggers, 1960; Florian, 1978; Leigh, 1987; Perlman \& Strudler, 1976; Polner, 1958; Rickard, Triandis, \& Patterson, 1963; Sears, 1975; Tagalakis, Amsel, \& FiChten, 1988; THOBEN, 1975; THORnton, 1998; Williams, 1972; Zuger, 1971). StONe AND SAWATZKI (1980) classified these factors into three specific areas: (a) numerous employment handicaps at the outset of a job search (e.g., lack of marketable skills, poor employment record), (b) management's misconceptions about what disabled persons bring to employment (i.e., lower productivity, higher absenteeism, higher accident rates, resentment of co-workers, negative attitudes, job site modifications, etc), and (c) the employment interview process (mainly the interviewer's preconceived negative impressions). Thus persons with disabilities have the same needs for employment as the general population, but face barriers to employment that may alter their experience of both working and job search.

More recent studies such as the Quebec Task Force on Whiplash-Associated Disorders (1995) have shown the importance of psychosocial factors in resolving the effects of noncatastrophic injuries resulting in employment problems. Unemployment is a stressful event that has been shown to have negative psychosocial and health consequences (DEAN \& Lin, 1977; DOHRENWEND, BS \& DOHRENWEND, BP, 1974; Greenblatt, Becerra \& Serafetinides, 1982; Liang, Dvorkin, KaHANA \& MaZian, 1980; Liem R \& Liem J, 1978; Pearlin \& Lieberman, 1979) and has been directly linked to depression, substance abuse and suicide (ATKINS, FERGUSON, \& Blankenship, 1983; DoOley \& CATALANO, 1988; Jones, 1991; Peregoy \& Schliebner, 1990; Shelton, 1985). Finding ways to mitigate the reactions to this psychological distress is necessary if a program such as Injury Recovery is to be effective.
The unemployment literature reveals several important factors regarding the importance of work. Western, industrialized and increasingly high technology societies place a great deal of value on gainful employment (FEATHER \& BOND, 1983; Winegardner, SiminetTi \& Nykodym, 1984). People's work environments may well represent the most important group membership and focus of time in their lives. In fact, URIS AND TARRANT (1983) suggested that the work group is more important than family, friends and community. Peregoy AND Schliebner (1990) examined the effects of long-term unemployment and found that people look to the work place to meet their needs for primary social interaction, and as a surrogate family system.

SulLIVAN (1972) linked Maslow's hierarchy of needs with employment and found that most people use work as a way of satisfying personal needs ranging from survival to self-actualization. ERIKSON (1980) suggested that productivity in the workplace is a major contributor to healthy ego identity. If this productivity is reduced or eliminated through unemployment, for example, ego identity is strained and begins to disintegrate. This weakened ego identity can lead to feelings of inadequacy, loss, and doubting of one's self-worth and belonging. ERIKSON (1980) suggested that if this occurs the individual can begin to stagnate and die.

SHELTON (1985) reviewed studies on the social and psychological impact of unemployment, which considered the economic costs of unemployment and the impact of unemployment on the individual and the family. Based on her review, Shelton stated that "professionals who work with the unemployed should be prepared to deal with depression, anxiety, and loss of self-esteem in the individual. These emotions may directly interfere with the job-seeking process".

A commonly held belief is that unemployment leads to psychological depression. However, FRESE AND MOHR (1987) suggested that empirical studies have had difficulty demonstrating a causal relationship and that it may be more appropriate to say that "depressed persons who are inactive and pessimistic in their outlook will be unemployed much longer or will become unemployed more readily" (p. 173). They further suggested that unemployment should not be viewed as one major life event, but rather as a life event that leads to a host of daily problems such as financial hardship and learned helplessness.

The concept of learned helplessness (SELIGMAN, 1975) is a useful framework through which to view the financial impact of unemployment. Learned helplessness is caused by repeated experiences of aversive, noncontrollable situations. A person caught up in learned helplessness exhibits passive, resigned, inflexible behaviour, linked to dysphoric feelings of depression brought on as a result of repeating these situations. The only escape from this condition is to exercise control over these situations. Individuals' reactions to being unemployed may be affected by how they explain the source of their job loss. People with an external locus of control are more passive, generally achieve less (LEFCOURT, 1976), and are more depressive (Prociuk, BreEn \& Lussier, 1976) than people with an internal focus. The locus of control construct refers to how people view themselves in conjunction with the events that befall them. The construct also encompasses the meaning that people give to the interaction between themselves and experiences (LEFCOURT, 1982). Individuals with an external locus of control tend to perceive experiences as the 
result of causes outside of their behaviors and thoughts. Conversely, people with an internal locus of control make sense of experiences in terms of their own actions and thoughts. If people do not understand experiences as a result of their actions, then the experiences, either positive or negative, are not effective in altering their locus of control and therefore have no impact on their actions.

GURNEY (1981) suggested that the kind of causal ascription made about unemployment by those who want to work can have important implications on their well being. He further stated that "their attribution about the reasons for not having a job may play an appreciable role on either intensifying or mitigating their feelings of failure and self-worth" (p. 79). Causal attribution has seen widespread academic interest arising out of the work of HEIDER (1944), who stated that "when we have a disagreeable experience, or a pleasant one, we may locate its origin in another person, in ourselves, or in fate" (p. 358). Later HEIDER (1958) limited attribution to two factors, internal or external. In interpreting how people choose among possible causes, attribution theorists have identified two general categories. The first category posits the perceiver as a systematic analyst looking for covariation between a given effect and different possible causes (KelLEY, 1967, 1971, 1973). The second categorizes the perceiver as tending to seek a single, salient, explanation for a behavior (JONES \& DAVIS, 1965).

Applying these two categories to predict the kind of causal attribution ICBC customers would make about their experience is useful. The conclusion can be drawn that people in the second category would look for a single external cause, like ICBC's handling of their claim, and be unlikely to change their causal attributions unless ICBC changed. The first category suggests that individuals would see many causes, apply the principles of consistency and distinctiveness (Kelley, 1973) and come up with internal reasons for their circumstances. An internal focus would make it easier for an individual to deal with their recovery and eventually return to work. However, GURNEY (1981) stated that this may not be the case. He suggested that causal attribution and locus of control are largely independent of each other. For example, some people may believe themselves to be powerless to change their circumstances thus exhibiting an external locus of control. However, the fact that they have not returned to work when others have may eventually lead them to see themselves as responsible for their predicament (an internal focus) and blame themselves for their situation. GURNEY (1981) concluded that this particular combination of an internal attribution with an external locus of control may be the cause for the devastating impact that unemployment has on self-esteem. We believe this to be equally true for ICBC customers trying to return to work post injury.

Since the 1950's there has been an increasing trend toward self-determination and personal planning with individuals taking control of their lives and accepting more responsibility for personal choices and life developments (FORSTER, 1985). An interest in the elements of personal decision making and planning has generated a great deal of academic and public attention on the concept of personal goal (FORSTER, 1985). Since establishing a personal goal is essential in career planning and job search, developments in the theory related to personal decision-making are relevant for designing programs to assist people to return to work. Forster concluded that "personal construct psychology would seem to be a theoretical framework well suited for the articulation and study of personal goals" (p. 261).

The fundamental unit in personal construct psychology is the "personal construct" (FORSTER, 1992). A personal construct is a transparent pattern created by individuals to organize the realities of their world. Individuals create constructs by deciding what theme is common in two or more events. This common theme is determined through a process of comparing and contrasting events until a similarity is found between at least two of these events. Personal constructs are developed over time, as a result of personal experience, and are formed into systems. Constructs provide a window or lens through which people perceive and understand events and also supply a mechanism for anticipating events and experiences. For example, suppose that a woman notices that her supervisor is more irritable at the end of the workweek than at the beginning of the week.

She has a construct that enables her to recognize irritability. She may also use related constructs such as (a) more rest on the weekend, and (b) time to participate in relaxing activities, as she attempts to interpret her experience with her supervisor and anticipate future interaction. FORSTER (1992) selected the personal construct as the "primary conceptual unit for investigating the elicitation and articulation of a person's goals" (p. 176).

Kortas, NeImeYer and Prichard (1992) stated that the area of employment was accepted as a logical field of study for investigating the application of the concept of personal construct because KELLY (1955), the creator of personal construct theory, felt that vocational development "is one of the principal means by which one's life role is given clarity and meaning" (p. 751). Construct systems developed by individuals in the course of their work experience are called vocational construct systems. Vocational construct systems might contain constructs like outdoor work, desk jobs, high wages and low salary. Individuals would use these constructs to organize and systematize their work experience and to anticipate future employment experiences. GIMENES (1990) assigned the label of vocational development construct to the interaction of: (a) the factors which motivate people to form vocational construct systems, (b) the elements which prevent people from forming vocational construct systems, and (c) the factors which trigger specific employment decisions. Since vocational development is based on work experience and all previous vocational decisions, Gimenes concluded that the construct clearly indicated that selecting an occupational goal is a complex process that takes time.

Evidence of some relationship between the level of integration in personal construct systems and decision-making has implications for the design of a treatment program that includes the identification of skills based on previous experience and the selection of new goals. A successful return to work post injury may require higher levels of integration of personal construct systems. All people, but particularly individuals faced with the reality of having to make substantial efforts in order to return to work, must reorganize their personal construct systems to incorporate both the experience of injury and recovery and the personal constructs that will guide their decision-making throughout their treatment and return to work process.

Based on the above, the following philosophy and mission statements were developed regarding IRP: 
Injury Recovery Philosophy:

To assist injured individuals in returning to work or usual activities by focusing on appropriate early intervention and early return to work/activity. Our goal is to get people better, faster by eliminating unnecessary bureaucratic red tape and unnecessary and inappropriate delays in the provision of medical and rehabilitation services.

\section{Mission Statement:}

Together with the medical and rehabilitation communities the Injury Recovery Coordinator will develop and fund individual injury recovery programs under the guidance of a medical manager, for our clients which will encourage early intervention, early recovery and return to work or return to normal activities while promoting the concept of wellness and maintaining a high standard of excellence in corporate customer service.

\section{The IRP goals were to:}

- Reduce costs by reducing the length of disability.

- Reduce length of disability by:

- Communicating with medical community.

- Insuring that individual rehabilitation plans are developed and monitored.

- Communicating with the employer community.

- Reduce lawyer involvement by treating people quickly, transparently, and fairly.

- Give the claims centres and BI adjusters a much-needed resource.

In order to achieve these goals it was recommended: That at least one recovery coordinator (RC) be added to every lower mainland claims centre. This position would be in addition to the current compliment of bodily injury adjusters, but would be drawn from their ranks. The $\mathrm{RC}$ will receive additional training to enable them to effectively communicate with the external community, especially the medical community. The RC will act as an expeditor to ensure that bureaucratic needs and systemic delays do not unnecessarily delay a client's recovery. The RC will NOT handle the tort aspect of a claim file (i.e., liability, settlement).

In order to be successful the RC:

- requires knowledge in the medical and rehabilitation fields;

- must have strong interpersonal and communication skills;

- must be perceptive and sensitive to personal and system needs that may impact on recovery;

- must keep a broad perspective yet be analytical when evaluating the unique needs of each client; and

- must be solution focused, pro-active, flexible and creative in striving for resolution of identified and potential problems.
Also, in order to be successful it was necessary to move forward in six separate but interdependent areas. These were the $\mathrm{RC}$, the $\mathrm{BI}$ adjuster, the rehabilitation/treatment network, the physicians, management/examiners and the clients.

Each one of these groups needed the following:

$\underline{\mathrm{RC}}$

- As outlined above.

$\underline{\text { BI adjusters }}$

- Training in medical and rehab issues;

- Education in the benefits of early RTW \& RTA; and

- Training in how to be a case manager.

Treaters

- Orientation to ICBC;

- Treatment plans;

- Timelines;

- Best practice guidelines;

- Outcome measurement;

- Accountability; and

- Communication.

Physicians

- Education;

- Information;

- Best practice guidelines; and

- Communication.

Managers/examiners

- Orientation;

- Training;

- Support; and

- Evaluation tools.

$\underline{\text { Clients }}$

- Communication;

- Managed expectations; and

- Knowledge of treatment protocols and timelines.

In order to have an effective injury recovery program we recommended that initiatives take place in parallel to address these needs.

For example, while the RCs were being selected and trained activities were underway with the medical and rehabilitation communities.

\section{Status}

The process of selecting and training the recovery coordinators began in October of 1998 . To date 50 bodily injury adjusters have received comprehensive specialized training to allow them to perform in the recovery coordinator role. While the majority of the RC's work in the greater Vancouver area, seven work in smaller communities throughout the Province. 
Training in disability management, including psychological factors in return to work have also been included in the curriculum for new bodily injury adjusters. Training sessions have, and will be, held outside the greater Vancouver area to assist offices in smaller communities where the workload does not warrant a dedicated internal resource.

\section{Evaluation}

An extensive formative evaluation was conducted in 2000. This evaluation was comprised of both qualitative and quantitative methodologies.

The qualitative evaluation showed that:

- the RCs had been well trained;

- the goals of the IRP were well received by stakeholders; and

- physicians in particular supported the program.

The quantitative evaluation showed that:

- the IRP was very effective with WAD II claimants, but not as effective with WAD I;

- the old culture of "deny \& defend" is still present and proving difficult to change;

- more work needs to be done on fostering communication both internally and externally;

- the impact on settlement costs is not as great as expected;

- the RCs may be exerting too much pressure on the claimants to RTW;

- management resources were inadequate to insure RC compliance with the program goals; and

- there is a need to refine the referral process.

In terms of hard numbers the IRP reduced:

- Length of physician treatment times for soft tissue BACK claims from 46.2 to 32.9 days.

- Length of physician treatment times for WAD II NECK and BACK claims from 58.0 to 49.7 days.

- Length of physician treatment times for WAD II, ALL INJURIES combined, from 57.1 to 55.6 days. Length of physiotherapy treatment times for WAD II NECK claims, from 63.12 to 42.96 .

- Length of physiotherapy treatment times for soft tissue BACK claims, from 47.7 to 16.8 days.

- Length of disability period measured from date of accident to date of case closure, from 128 to 117 days.

The IRP also decreased lawyer involvement from a corporate average of approximately $30 \%$ to a program average of $15 \%$.

\section{Conclusions}

Given the initial findings of the formative evaluation, steps were taken in 2001 to build on the strengths and address the identified weaknesses of the program. One area of weakness that was addressed was the lack of management resources. Two managers were selected to assist with the ongoing development of the recovery coordinators and to ensure consistency within the program.

Before the changes could be fully implemented however, ICBC conducted a core business review resulting in drastic organizational changes. One result was that all programs requiring specialized staff were dismantled and the injury recovery program was one of them.

Despite canceling the program ICBC recognized the value of the disability management approach and steps are being taken to integrate the disability management approach of handling customer's claims into the claims process and performance standards for all adjusters.

\section{REFERENCES}

1. ACTON N. Employment of disabled persons: Where are we going? International Labour Review 1981;120:1-14.

2. AtKinson B, Fergusen N, BlanKenship ML. Unemployment is rough on families. Vocational Leadership 1983;58:29-30.

3. BEAN BR, BEARD JH. Placement for persons with psychiatric disability. Rehabilitation Counseling Bulletin 1975;18:253-8

4. BALDWIN ML, JoHnson WG. Dispelling the Myths about Work Disability. In T. Thomason, J.F. Burton, Jr. \& D.E. Hyatt (Eds.), New Approaches to Disability in the Workplace. Madison, WI: Industrial Relations Research Association, 1998;39-61.

5. Borgen WA, Amundson NE, Biela PM. The experience of unemployment for persons who are physically disabled. Journal of Applied Rehabilitation Counseling 1987;18:25-32.

6. BRENNER SO, LEVI L. Long-term unemployment among women in Sweden. Social Science Medicine 1987;25:153-61.

7. BRICOUT JC, BeNtLey KJ. Disability status and perceptions of employability by employers. Social Work Research, 2000;24(2): 87-99.

8. COHEN JS. Employer attitudes toward hiring mentally retarded individuals. American Journal of Mental Deficiency 1962;67: 705-13.

9. DeAn A, Lin N. The stress-buffering role of social support. The Journal of Nervous and Mental Disease 1977;165:403-17.

10. Dohrenwend BS, Dohrenwend BP. Overview and prospects for research on stressful life events. In B. S. Dohrenwend \& B. P. Dohrenwend (Eds.), Stressful life events: Their nature and effects. New York: John Wiley \& Sons 1974;313-31.

11. Dooley D, Catalano R. Recent research on the psychological effects of unemployment. Journal of Social Issues 1988;44:1-12.

12. DYCK DEG. Disability Management: Theory, Strategy and Industry Practice. Toronto: Butterworths, 2000.

13. EGGERS ET. Employment of the physically handicapped: A survey of industrial plants in Atlanta, Georgia. Industrial Medicine and Surgery 1960;29:427-33.

14. ERIKSON EH. Identity and the life cycle. New York: International University Press, 1980.

15. FEATHER NT, BOND MJ. Time structure and purposeful activity among employed and unemployed university graduates. Journal of Occupational Psychology 1983;56:241-54.

16. FLORIAN V. Employers' opinions of the disabled person as a worker. Rehabilitation Counseling Bulletin 1978;22:38-43.

17. FORSTER JR. Investigating personal goals using personal construct theory and grid methods. In F. Epting \& A. W. Landfield, (Eds.), Anticipating Personal Construct Psychology. Lincoln, NE: University of Nebraska Press, 1985:261-71.

18. FORSTER JR. Eliciting personal constructs and articulating goals. Journal of Career Development 1992;18:75-185.

19. Frese M, Mohr G. Prolonged unemployment and depression in older workers: A longitudinal study of intervening variables. Social Science Medicine 1987;25:173-8.

20. GIMENES MG. Theoretical perspectives. In C. Schiro-Geist (Ed.), Vocational Counseling for Special Populations. Springfield,IL: Charles C. Thomas, 1990:19-43.

21. Greenblatt M, Becerra RM, Serafetinides EA. Social networks and mental health: An overview. American Journal of Psychiatry 1982;139:973-84.

22. GURNEY RM. The effects of unemployment on the psychosocial development of school-leavers. Journal of Occupational Psychology 1980;53:205-13.

23. HeIDER F. Social perception and phenomenal causality. Psychological Review 1944:51:358-74. 
24. HeIDER F. The psychology of interpersonal relations. New York: Wiley, 1958.

25. JAHODA M. Employment and unemployment: A social-psychological analysis. London: Cambridge University Press, 1982.

26. Jones EE, Davis KE. From acts to dispositions. In L. Berkowitz (Ed.), Advances in experimental social psychology: Vol. 2. New York: Academic Press, 1965.

27. JONES LP. Unemployment: The effect on social networks, depression, and reemployment opportunities. Journal of Social Science Research $1991 ; 15: 1-22$.

28. Kaufman HG. Professionals in search of work: Coping with the stress of job loss and underemployment. New York: Wiley, 1982.

29. Kelley HH. Attributional theory in social psychology. In D. Levine (Ed.), Nebraska Symposium on motivation. Lincoln, NE: University of Nebraska Press, 1967:192-238.

30. Kelley HH. Causal schemata and the attribution process. New York: General Learning Press, 1971.

31. Kelley HH. The processes of causal attribution. American Psychologist 1973;28:107-28.

32. Kelly GA. The psychology of personal constructs, Vol. $1 \& 2$. New York: W. W. Norton \& Company, 1955.

33. Kelvin P. Work as a source of identity: The implications of unemployment. British Journal of Guidance and Counselling 1981;9:2-11.

34. Kortas L, Neimeyer GJ, Prichard S. Structure and style in career decision making. Journal of Career Development 1992;18:199-213.

35. LEFCOURT HM. Locus of control: Current trends in theory and research (2nd ed.). Hillsdale, NJ: Lawrence Erlbaum Associates, 1976.

36. LEIGH JP. The effects of unemployment on the probability of suffering a disability. Work and Occupations 1987;14:347-67.

37. Liang J, Dvorkin L, Kahana E, Mazian F. Social integration and morale: A re-examination. Journal of Gerontology 1980;35:746-57.

38. LIEM RG LIEM JH. Social support and stress: Some general issues and their application to the problem of unemployment. In L. A. Ferman \& J. Gordus (Eds.), Mental health and the economy. Kalamazoo, MI: Upjohn Institute for Employment Research. 1978;347-77.

39. MASLOW AE. Toward a psychology of being (2nd ed.). Toronto: D. Van Nostrand, 1968.

40. Neimeyer GJ. Personal constructs in career counseling and development. Journal of Career Development 1992;18:163-73.

41. Orwell G. The road to Wigan Pier. San Diego: Harcourt Brace Janovich, 1972.

42. Pearlin L, Lieberman M. The social sources of emotional distress. Research in Community Mental Health 1979;1:217-42.

43. Peregoy JJ, Schliebner CT. Long-term unemployment: Effects and counseling interventions. International Journal for the Advancement of Counselling 1990;13:193-204.

44. Perlman LG, Strudler LA. The epileptic citizen: An employment perspective. Journal of Rehabilitation 1976;42:36-40.

45. POLNER W. Hiring limitations on cardiacs in Chicago area firms. Industrial Medicine and Surgery 1958;27:316-20.

46. Prociuk TJ, BreEn LJ, Lussier RJ. Hopelessness, internalexternal locus of control and depression. Journal of Clinical Psychology
1976;32:299-300.

47. Rickard TE, Triandis HC, Patterson CH. Indices of employer prejudice toward disabled applicants. Journal of Applied Psychology $1963 ; 47: 52-5$

48. RuMP EE. A comment on Dowling and O'Brien's 'employed' and 'unemployed' groups. Australian Journal of Psychology 1983;35:89-90.

49. Schaufeli WB. Perceiving the causes of unemployment: An evaluation of the causal dimension scale in a real-life situation. Journal of Personality and Social Psychology 1988;54:347-56.

50. SEARS JH. The able disabled. Journal of Rehabilitation $1975 ; 41(2): 19-22$.

51. Seligman MEP. Helplessness: On depression, development and death. San Fransciso: Freeman, 1975.

52. SHAW D. Unemployment hurts more than than just the pocketbook. Today's Health, 1976, March 23-26.

53. SHELTON BK. The social and psychological impact of unemployment. Journal of Employment Counseling 1985;22:18-22.

54. StOne CI, SAWATZKI B. Hiring bias and the disabled interviewee: Effects of manipulating work history and disability information of the disabled job applicant. Journal of Vocational Behavior 1980;16:96-104.

55. Sullivan DR. Maslow's hierarchy of needs in relation to employment. Journal of Employment Counseling 1972;9:94-5.

56. TAGAlaKis V, AMSEL R, FiCHTEN CS. Job interview strategies for people with a visible disability. Journal of Applied Social Psychology 1988;18:520-32.

57. Thoben PJ. Civil rights and employment of the severely handicapped. Rehabilitation Counseling Bulletin 1975;18:240-4.

58. Thomason T, Burton JF, Hyatt DE. Disability in the workplace. In T. Thomason JF Burton, Jr., DE Hyatt (Eds.), New Approaches to Disability in the Workplace. Madison, WI: Industrial Relations Research Association, 1998:1-37.

59. Thornton P. Preface. In M. Gunderson, A. Gildiner, \& A. King (Eds.), International Research Project on Job Retention and Return to Work Strategies for Disabled Workers. Geneva: International Labour Organization 1998.

60. Tiggemann M, Winefield AH. The effects of unemployment on the mood, self-esteem, locus of control and depressive affect of school leavers. Journal of Occupational Psychology 1984;57:33-42.

61. Toffler A. The third wave. New York: Bantam Books, 1980.

62. Uris A, Tarrant J. Career stages. New York: Seaview/Putman, 1983.

63. WILliams CA. Is hiring the handicapped good business? Journal of Rehabilitation 1972;38:30-4

64. Winefield AH, Tiggemann M, Smith S. Unemployment, attributional style and psychological well-being. Personality and Individual Differences 1987;8:659-65.

65. Winefield AH, Tiggemann M, Winefield HR. The psychological impact of unemployment and unsatisfactory employment in young men and women: Longitudinal and cross-sectional data. British Journal of Psychology 1991;82:473-86.

66. Winegardner D, SimonetTi JL, NyKODYM N. Unemployment: The living death? Journal of Employment Counseling 1984;21:149-55.

67. ZUGER R. To place the unplaceable. Journal of Rehabilitation $1971 ; 37: 22-3$.

This material was presented at the International Congress on Whiplash Associated Disorders, Berne, Switzerland, March 8 to 10, 2001. The paper appeared originally in the book "Whiplash Associated Disorders" - medical, biomechanical and legal aspects, published by Staempfli Publishers Ltd,

Berne 2002. The paper is published in North America in Pain Research $\mathcal{E}$ Management with the permission of Staempfli Publishers Ltd. 


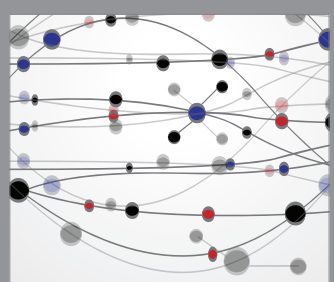

The Scientific World Journal
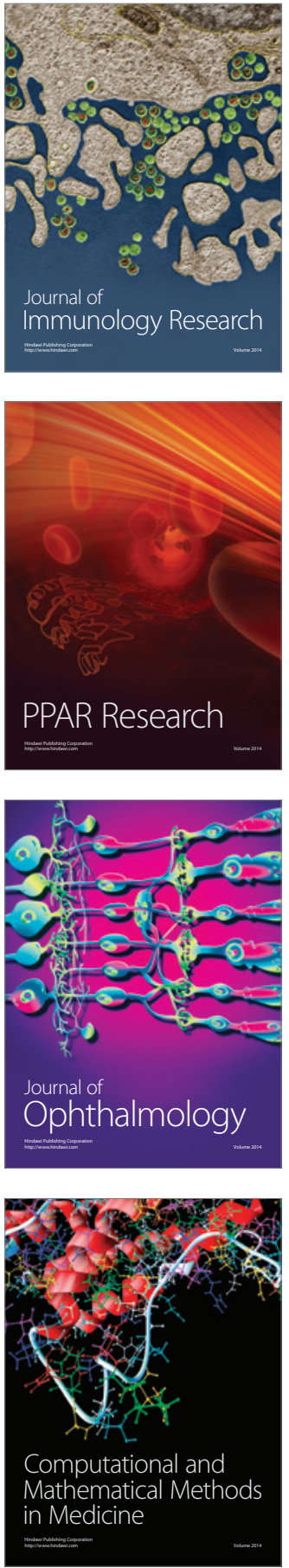

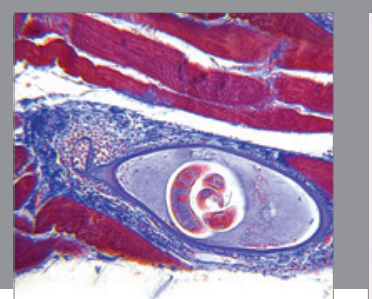

Gastroenterology Research and Practice

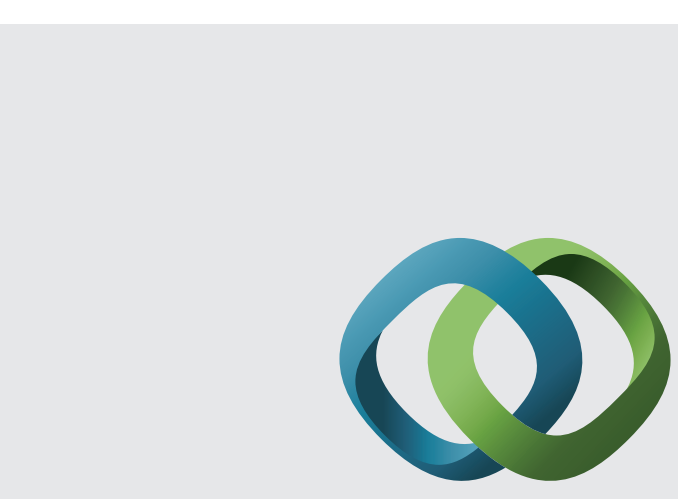

\section{Hindawi}

Submit your manuscripts at

http://www.hindawi.com
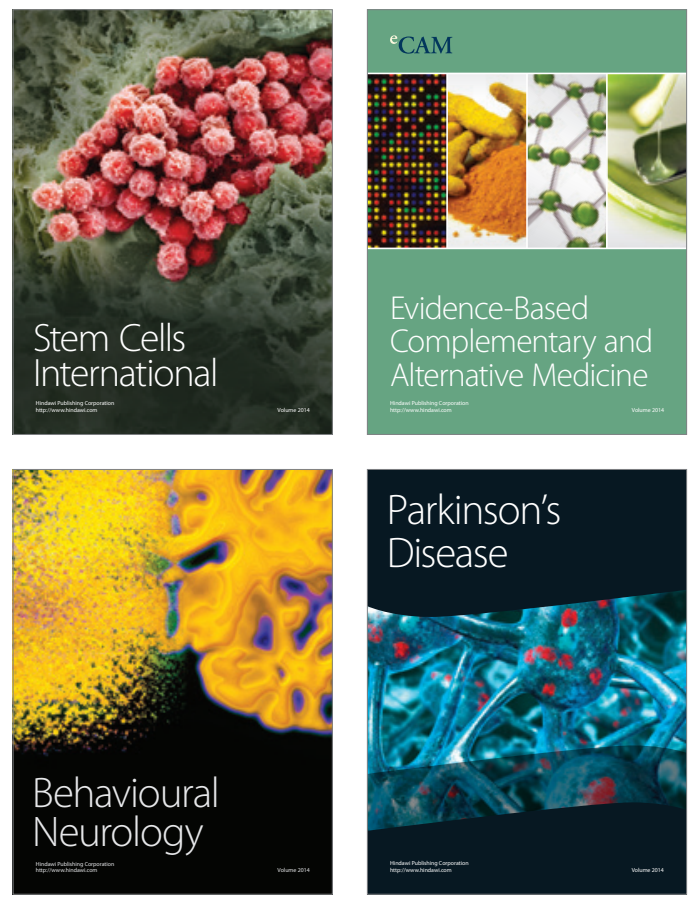
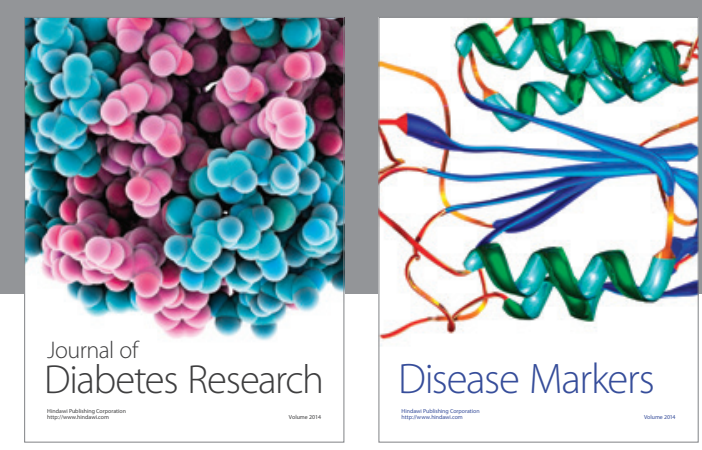

Disease Markers
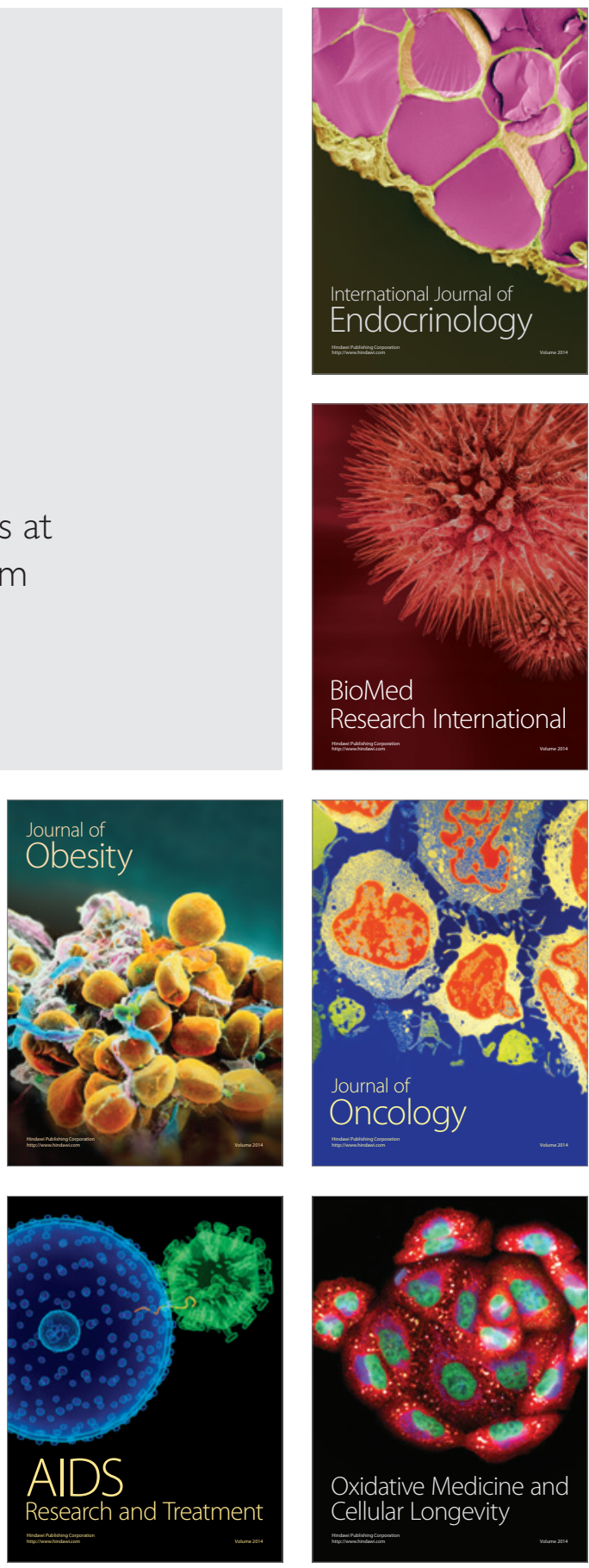